\title{
DIGITAL DIPLOMACY VERSUS DOWNFALL. AN AGENDA FOR INTERNATIONAL RELATIONS IN THE GLOBAL AGE ${ }^{1}$
}

\begin{abstract}
There are numerous global challenges facing humanity in this century. Diplomacy has to take these needs into account and contribute with profound expertise to academic and political discussions as well as societal developments. Any single state-related or disciplinary solo effort will not provide adequate answers to how humanity can manage and cope with the global risks of the $21^{\text {st }}$ century.

The article deals with the question of digital diplomacy versus downfall by first outlining the global hazards endangering humanity as well as influencing world politics and international relations. Thereafter digital diplomacy as a tool to prevent humanity's downfall is presented. Requirements for diplomats in the global age are highlighted in the following. Furthermore, visionary claims of a global turn in politics are designated and diplomacy's contribution toward this undertaking are formulated. To close, diplomacy's most promising way of offering humanity its profound expertise in the digital era is set forth.
\end{abstract}

Keywords: global risks, humanity's downfall, digital diplomacy, global age, international relations.

DOI: 10.51180/RPS.2020.15.2.001.

Author

\section{Wittmann Veronika}

Assoz. Univ.-Prof. Dr. Mag. Associate Professor Global Studies JOHANNES KEPLER UNIVERSITY LINZ

(Linz, Austria)

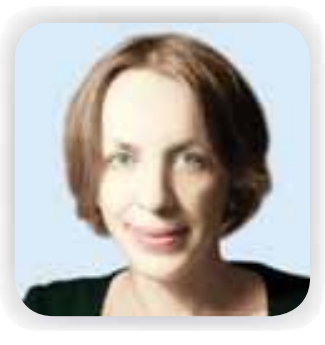

\section{Global risks endangering humanity}

Aransnational terrorism, climate change, the loss of biodiversity, pandemics like Covid-19, information infrastructure breakdown, cyber security, the lack of global technology governance etc ${ }^{2}$. Are all current risks that transcend national or world-regional borders and have to be categorized as global risks endangering the whole of humanity. As such, no one is unaffected by these hazards. At the same time these global risks show the vulnerability of world regions and specific groups. The current Covid-19 pandemic can function as an adequate example for this argument. It is a fact that everybody is confronted with this new virus, such as the British Prime Minister Boris Johnson who got just as sick as a woman living in a disenfranchised community in Mumbai. So Covid-19 cuts across social or sex or age groups as well as any specific locus of a person; in other words: it is a global human experience.

At the same time, the pandemic revealed the vulnerability of world regions

\footnotetext{
1 This article is based on the presentation held at the International online conference "New Digital Reality: Science and Education, Law, Security, Economics and Finance", Zoom-Videoconference organised by the Russian Political Science journal and the Global Processes journal on 6th - 11th July 2020.

${ }^{2}$ For world-spanning hazards, see the Global Risk Report [40], published by the World Economic Forum on an annual basis since 2005 .
} 
and specific groups. According to the UN World Water Development Report 2019 [33], which is published by UNESCO on an annual basis, every third person on this planet - 2.1 billion people - does not have access to a safe drinking water supply and as such cannot properly wash their hands with water and soap. Washing hands with soap can be seen as one of the greatest advances in human hygiene, but due to lack of access to clean water it is of little use to large parts of humanity. So, although mankind as a whole is endangered by global risks, the ways of coping with it reveal the different vulnerabilities of various people.

On a political scale, Covid-19 has led to various reactions by governmental representatives across the globe. In this context diplomats are perceived as important actors in world politics and international relations whose working spheres changed due to the current pandemic. Diplomats all over the world have been using digital information and communication technologies to send information to their citizens in this time of global crisis. Generally, digitalization processes will alter the essence of current diplomacy [for an overview on contemporary diplomacy, see $2 ; 5 ; 15 ; 21$; 22] and its prospective directions both at theoretical as well as practical level. Digital diplomacy [for an overview on digital diplomacy, see $4 ; 24 ; 29]$, as understood here, looks at the transition from traditional channels to modern forms of diplomatic communication, thereby new techniques of diplomacy arise from digital information and communication technologies as well as social media. There is a variety of debates around the terminology in digital diplomacy. The spectrum of terminological descriptions ranges from e-diplomacy, diplomacy 2.0., cyber diplomacy, net-diplomacy et al.; thereby each term has a joint perspective in common: the use of digital information and communication technologies to accomplish diplomatic objectives. Here, digital diplomacy refers to the use of digital information and communication technologies - from videoconferencing to social media platforms - by diplomats as global actors in world politics and international relations.

In the context of the contemporary infectious disease confronting all states and as such all of humanity, digital diplomacy can be seen as a very constructive and powerful tool for exchanging knowledge regarding how to best deal with the new virus. Yuval Noah Harari [16] in the article "The world after coronacrisis", published in Financial Times, raises two particularly important choices that humanity has to decide on in this century: the first choice is between totalitarian surveillance and citizen empowerment. And the second is between nationalist isolation and global solidarity. The first choice clearly points to the question of surveillance tools used by governments to reduce the number of infected people versus educational tools and self-responsibility of citizens by empowerment schemes used by governments to create a well-informed and self-motivated population as a strategy to minor the infection circle. So, the world's governments have perceived different strategies for dealing with the current pandemic, and diplomats - as being part and parcel of international relations have also used various tools depending on the political framework of the state sending them. The second choice which humanity has to decide on - the one between nationalist isolation and global solidarity - is described by Yuval Noah Harari [16] in the following words:

Humanity needs to make a choice. Will we travel down the route of disunity, or will we adopt the path of global solidarity? If we choose disunity, this will not only prolong the crisis, but will probably result in even worse catastrophes in the future. If we choose global solidarity, it will be a victory not only against the coronavirus, but against all future epidemics and crises that might assail humankind in the $21^{\text {st }}$ century.

At this point, global crises like the current pandemic can be interpreted as 
a wake-up call for states, world-regions and all of humanity that global disunity will not only cause humanitarian disasters, but will also lead to even worse catastrophes in the future. Here the role of diplomats as global actors in world politics and international relations is decisive for the future of humanity. Diplomats in this context can be seen specifically as skilled experts who have expertise in trying to solve conflict situations not in a military way, but in a peaceful manner. More than other professionals, they are trained to figure out constructive ways of solving difficult and complex political scenarios. Digital diplomacy can hereby function as a contemporary tool for reaching global understanding in a world faced with a common crisis.

Not being able to reach mutual agreements and international cooperation among states in an era of global crises endangering mankind would lead to the downfall of mankind. Unilateral actions of states implicate an impending demise of humanity, whereas multilateral actions can constructively figure out ways of reducing global risks. Thus, digital diplomacy as part and parcel of multilateral actions can be an effective and constructive tool for strengthening cooperation among states, for sharing knowledge about global hazards and for creating an atmosphere of confidence in the political arena across the various parts of the world.

In this understanding, a worst-case scenario in world politics and international relations would be one where every state is trying on its own to overcome global hazards. Such a parochial undertaking would lead humanity to its downfall. The normative argument is not only that in world politics and international relations cooperation serves the citizens of all participating states better than isolation, but also the given fact that global challenges facing mankind in this century are too big for any single state to cope with on its own. It is therefore a question of rationality that states cooperate multilaterally, to exchange knowledge about dealing with global risks, to reach mutual agreements between states to solve the world-wide hazards facing humanity, and to perceive potential solutions to overcome global crises as a joint endeavour. This perception of the role of states is rooted in cosmopolitan approaches [for an overview on cosmopolitanism, see 7 ; $8 ; 11 ; 13 ; 20 ; 28]$. As such it opposes the idea that states are not capable of cooperating and finding multilateral agreements, a view being articulated by the realist school of international relations [for an overview on realism, see $3 ; 12$; $14 ; 17 ; 35 ; 37 ; 38 ; 39]$. In the cosmopolitan tradition states are not only perceived as capable of cooperation, but furthermore it is stated that in the long run this is the only way states can survive. To put this normative view more precisely, one can state that those states who take the national card will lose.

The Global Risks Report 2020, published by the World Economic Forum [40], lists among the central risks the world will be facing in 2021 - besides climate change and economic stagnation - a fragmented cyberspace which menaces the full potential of next-generation technologies, as well as the lack of contemporary technology governance. As such, governments across the globe share the responsibility of promoting digital confidence. Cooperation between states as well as the private and public sectors is a necessity of the digital era in areas like information sharing and skill and capacity development. In this world-spanning process, diplomats play a decisive role as global actors.

\section{Digital diplomacy: a tool to prevent humanity's downfall}

As much as digital information and communication technologies have had an impact on world politics and international relations as well as on humanity, it is evident that the professional working fields of diplomats are also influenced and changed due to digitalization processes. 
Overall, diplomats are here seen as an epistemic community, as such as "a network of professionals with recognized expertise and authoritative claims to policy-relevant knowledge in a particular issue area" [9]. Diplomats can be located in different states and may hail from various backgrounds, but as professionals they share a joint policy enterprise and a common criteria for evaluating knowledge as well as they share a common set of norms that motivate their joint action.

Furthermore, they also share a set of beliefs concerning essential problems in their area of expertise. As such, diplomats play a vital role as a network of global actors in world politics and international relations. They can reach consensus in difficult political scenarios and their work has an impact on state policies and interstate cooperation.

The working sphere and also the tools with which diplomats work has changed over the centuries. At the turn of the third millennium, humanity was already living in a global age, as scholars like Martin Albrow [1] have described it. Digital information and communication tools have changed world politics and international relations as well as humanity rapidly in the last decades. As such, using these tools in their workspaces can be interpreted as an essential for diplomats in contemporary times.

Digital diplomacy is a contemporary tool for preventing humanity's downfall, and it is a universal agenda: Diplomats as global actors can make a substantial contribution to a joint understanding of our common digital future and be architects of a "global commitment for digital cooperation" [see 32]. As such, digital diplomacy as it is being outlined here is a highly relevant agenda for international relations in the global age. It is a pressing necessity of time for world politics and humanity living in an era coined by common risks. Furthermore, digital diplomacy enables an improvement of transparency in informing citizens on state policies at a national and international level. And last but not least, it paves the way for solving the global challenges humanity is facing in a peaceful manner.

Digital diplomacy must be shaped in such a way that it can serve as a pillar for humanity in overcoming global crises. Digitalization has already had a profound and deep effect on political and socioeconomic systems across the globe and will continue to do so in this century. As such, it has a huge and far-reaching impact on world society, world politics and international relations and must therefore be managed accordingly. In this world-spanning process, diplomats play a decisive role.

The future of humanity will depend profoundly on the progress of digitalization processes, and diplomats are challenged to participate in this world-spanning trend by using digital diplomacy as a tool in their working fields. This endeavour might lead to new directions in international relations across the globe, but it has to be seen as a necessity of the global age. In order to fulfil the requirements of diplomacy in this era, it needs to share its expertise by means of digital information and communication technologies. The rapid advances in the field of digital information and communication technologies can assist humanity in solving global crises, and diplomats are highly relevant global actors in this joint endeavour.

\section{Requirements for diplomacy in the global age}

The requirements for diplomacy in the global age can be highlighted on the basis of a list of criteria. Criteria that diplomacy has to meet are as follows:

First, diplomacy has to orientate itself on a given social and societal reality. This reality in the $21^{\text {st }}$ century is generated by global and digital dynamics. There is no single state or world region across the globe which is not affected by globalization processes [for an overview on 
globalization, see $23 ; 25 ; 26 ; 27 ; 30]$ and digitalization trends. Although only 4.1 billion people across the globe are using the internet, meaning that nearly half of the world's population so far remains digitally excluded [18], it is clear that processes of digitalization will increase in the coming decades, including societal participation and political involvement.

Second, diplomacy has to consider global consciousness as a worldwide experience of people. Globality is a given reality of human beings and should be considered for future international relations. One example of this could be raising the awareness of people across the globe on the need to live harmoniously together on Planet Earth and as such the argument to share its resources in a sustainable way. A further example is the notion of world citizenship raised by Immanuel Kant [19; see also 6] in his writings on eternal peace. The perception of Immanuel Kant and his notion of a world citizenship form the basis for contemporary cosmopolitan approaches.

Third, diplomacy has to deal with social and political structures, processes and relations which are world-spanning. E.g. transnational civil society organizations are increasingly highly influential and significant actors in world politics. There is an increasing political power shift taking place at a global political level; states are no longer the only players in this field. Specifically, world-spanning topics on human rights and environmental issues are raised by international non-governmental organizations and are gaining momentum in world politics [for an overview on the role of international non-governmental organizations and international relations, see 10]. At various UN conferences taking place throughout recent decades, the influence of international non-governmental organizations on a global political scale has become clearly visible. The Paris Agreement [34] signed by all UN states in 2015, which aims to strengthen the global response to the menace of climate change, was also a result of the work of international non-governmental organizations pushing the environmental agenda on governmental policies across the world. Digitalization can be seen as one of the large challenges of diplomacy in a less state-centric world.

Fourth, diplomacy has to meet the requirements of the digital age. Digitalization "герresents nothing less than a civilizational revolution" [36], and diplomacy is part and parcel of this global development. Technological changes will have enormous influence on humanity in this century. Digital information and communication technologies, as well as artificial intelligence, change social and societal structures, processes and relations in a profound and sustainable way. Working spheres, politics, consumer habits and the social and societal life-like relations and interactions of people will alter due to technological innovations. Elections, for example as part of the political decisionmaking processes, take place digitally in various parts of the world and people earn the right to politically participate by using digital information and communication technologies via social media.

Rapid technological changes taking place on a global scale will mould the future of diplomacy as much as technological innovations and alterations will to a large extent shape humanity in this century. The effects caused by digital information and communication technologies as well as artificial intelligence on social, political, economic and cultural areas of life will be far-reaching and longlasting. In order to capture these changes, diplomats have to be well trained on how to use digital information and communication technologies in an optimal manner.

Processes of digitalization and the technological innovations of the digital age cause profound and sustainable changes of social and societal structures, interactions and relations. Borders shift enormously: borders between human beings and robots, between physical and 
digital social life, borders real and virtual life etc. Place and time as categories of social and societal life are being redefined by digital information and communication technologies as well as artificial intelligence. All these aspects require new perspectives, not only for governmental policies in specific states; but they also indicate a necessary shift for diplomats as being part and parcel of the international community. In this century there is a need for a global turn of politics due to the world-wide dynamics of technological innovations, and diplomats can contribute their expertise here.

In addition to this it is obvious that space as a reference point of social and societal life is losing its relevance due to digital information and communication technologies. The locus of a person is no longer important for social and societal interaction and communication, as it was decades ago. Diplomacy as understood here acknowledges the interconnectivity of the virtual world - e.g. social media, and the real world - face-to-face human interaction. Regarding both, digital diplomacy can be a recognition of the world's diversity.

And the fifth point is that diplomacy has to actively participate in digital processes and the visionary claims of a global turn in politics. Digital participation is an essential of contemporary diplomacy and part and parcel of future politics and international relations.

Considering the interface topics of diplomacy and technology, it is evident that both global risks as well as digital information and communication technologies as a global human experience create transnational similarities. Furthermore, political decisions are made within a few hours in times of global crisis. This is something that all people have been experiencing in the current pandemic caused by the SARS-CoV-2 virus. Immature or even dangerous technologies are implemented by governments all over the world, because the risks of doing nothing are considered greater. Political decisions are hereby often made on the basis of reasonable [secure] not-knowing. All countries of the world are currently acting as "guinea pigs in large-scale social experiments" as Yuval Harari [16] has stated. The political measurements being taken by several governments across the world when confronted with the pandemic have openly brought about a discourse between interfering with the fundamental rights of people, even in consolidated democracies, and the urge for data protection issues versus surveillance tools in autocratic or totalitarian political systems. Technological innovations make it possible for the first time in human history to constantly monitor everyone. As such the current pandemic marks a turning point in the history of surveillance. In addition to mobile tracing-apps, some governments of the world could also use biometric wristbands, which would mean a transition to a frightening new surveillance system [see 16]. In this epoch totalitarian surveillance often applied in autocratic or totalitarian political systems, but also raised in consolidated democracies - contrasts with citizen empowerment. Technological innovations could lead humanity in either direction in this century.

In the digital and global age, analyses of the interaction between many actors are needed: an informed world public and serious media coverage, a global civil society, states that do not lose themselves in nationalist isolation but develop new forms of multilateralism and responsible politics. And this also requires sound scientific expertise, e.g. to deal with changes in knowledge and power through digital information and communication technologies and governance. In the face of global crises, people must have confidence in politics and well-functioning international relations, in science as well as new technologies. Innovative technologies used by diplomats can hereby assist in building this confidence on a world-wide scale.

In this sense, diplomacy has to perform wide-ranging tasks in this era. 


\section{The visionary claims of a global}

turn in politics, and diplomacy's contributions toward this undertaking

The visionary claims of a global turn in politics, and diplomacy's contributions toward this undertaking through considering the political development trends in the 21st century are based on the following three assumptions:

First, the challenges for humanity in the $21^{\text {st }}$ century are enormous. Global crises shape human life all over the world. Global challenges and crises require innovative, cross-disciplinary and transnational spaces and also address the need for global cooperation: No academic discipline or state alone can cope with these universal threads. One example of this is Darknet, an overlay network within the internet and part of the greater deep web, which is overthrowing traditional forms of political power. No state across the globe is unaffected by it. As such, there is no single state in the world that is not being challenged by this big part of the internet which is to a large extent changing political power in the traditional sense. To put it plainly, this means that Darknet is not governable by any political regime across the globe.

Second, rapid technological changes will cause the substantial transformation of human life in this century. At the same time, technological alterations and opportunities as well as the risks of digitalization taking place on a global scale will also shape the future of diplomacy itself. As such, diplomacy has to meet the requirements of the digital age in terms of their professional training. In this century, a profound and firmly-based education on how to use digital tools is a necessity for any curriculum of diplomatic professional training programmes. Training on the usage of digital information and communication technologies is crucial for the diplomatic corps across the globe.

Third, diplomacy is a key player in developing a global plan for humanity. Global risks themselves that affect all people as well as the resulting social, political, cultural and economic crises are universal problems. Information and knowledge in dealing with global crises must be shared on a world-wide scale by diplomats as global actors. Diplomacy must provide expertise on perceiving the dilemma of global discordance in a world society and world politics confronted with global crises.

Diplomacy can be seen as a key actor in developing a global plan for humanity. Global risks themselves that affect all people, as well as the resulting social, political, cultural and economic crises, are universal problems. These can only be solved effectively through global cooperation and can only be addressed by common diplomatic endeavours on a transnational basis. As stated above, Covid-19 or any other pandemic, surveillance tools, transnational terrorism, nuclear threats, climate change, cyber-attacks etc. affect people worldwide - from the British Prime Minister to a Mumbai slum dweller. What is needed in this century is diplomatic expertise focusing on global human experiences. Information and knowledge in dealing with global crises must be shared globally. As much as in the case of realpolitik, a coordinated global political effort can ensure that, for example, life-saving equipment is distributed fairly among states; accordingly, diplomats also have at the same time a common assignment. It is one of the tasks of diplomats worldwide to create sound expertise in dealing properly with these global human experiences.

Digital information and communication technologies, as well as artificial intelligence, are essential tools for the future development of world society and the shaping of world politics and international relations. Therefore, diplomacy has to embrace these tools as a medium of communication. Only by doing so can it effectively contribute to the visionary claims of a global turn in politics.

Digital diplomacy can make significant contributions in the global and digital age by considering a new comprehension of 
diplomacy; an understanding of diplomacy that is open to facing the challenges of a humanity confronted with global risks, transnational similarities and rapid technological changes. And this would follow a professional approach that develops concepts and opens discourses on the social, economic, cultural and political shaping of the world and the digital empowerment of world citizens in the global age.

Taking the need for a global turn in politics into account: Immanuel Kant has to be revisited. In his writings on eternal peace he pointed out that need compels insight and he addressed the ius cosmopoliticum, the world citizenship. More than 220 years later, in the face of global crises, humanity is at a crossroads between the Leviathan figure of Thomas Hobbes [31] - surveillance through new technologies and the handling of global crises by autocratic political systems as well as the emphasis on security - versus Immanuel Kant's insight that people all over the world are reasonably gifted and free beings, who only survive through global cooperation.

\section{Diplomacy's most promising way of offering humanity its profound expertise in the digital era}

Digital diplomacy can make significant contributions in the global age by considering an understanding of diplomacy that is open to face the challenges of a humanity confronted with global risks, transnational similarities and rapid technological changes. And this follows a professional approach that develops concepts and opens discourses on the socio-economic and political shaping of the world and the digital empowerment of world citizens.

The role of digital diplomacy will increase in this century due to the fact that technological innovations and digital information and communication tools will continue to shape world politics, international relations and humanity to a large extent. States can use digital diplomacy in a constructive way to find joint solutions to solve global crises and face the world-spanning challenges that lie ahead of humanity. It can be used as a tool for enabling knowledge-transfer, to exchange political views, to give information to citizens and also to demonstrate transparency on governmental activities at a national and international level. In the global age, digital diplomacy is a modern tool to create understanding and awareness across the globe on world-spanning issues.

What is needed in this century to give adequate answers to the challenging questions of humanity is universally shared knowledge in dealing with global risks as such a global turn in politics. Diplomats can hereby strengthen their roles as global actors by using digital information and communication technologies as part and parcel of their working fields, and at the same time function as relevant actors on a global stage for establishing an environment of confidence among states and world regions. This will be no easy task, but it is diplomacy's most promising way of offering humanity its profound expertise in this era.

After analysing the question of digital diplomacy versus downfall, the conclusion reached here is the following: it must be plainly stated that digitalization processes, although they are so far yet to reach all parts of the world, will have an immense impact on the shaping of world politics and international relations as well as humanity. However, up to now digital diplomacy is only beginning to become an essential tool for diplomats in their daily work routine. The sooner states invest in training programmes for using digital information and communication technologies as a means in the working arena of diplomats, the better the outcome will be for specific states, for world politics and international relations as well as for humanity. The core challenge for the international community now is to develop the common architecture of a digitally supported future and to establish collective principles and regulatory framework conditions, as are being outlined by the United Nations [32]. 
An open and interconnected cyberspace alongside a common architecture of its governance is essential in order for humanity to cope with global risks in this century. Digital diplomacy can thereby play a decisive role by promoting gov- ernance frameworks and building confidence between states and world-regions across the globe. As such humanity can increasingly benefit from diplomats as global actors in the digital era.

\section{References}

1. Albrow, Martin [1996]: The Global Age. State and Society Beyond Modernity. Stanford: Stanford University Press.

2. Barridge, G. R. [2015]: Diplomacy: Theory and Practice. Fifth Edition. London: Palgrave Macmillan.

3. Bell, Duncan [Ed.] [2008]: Political Thought in International Relations: Variations on a Realist Theme. Oxford: Oxford University Press.

4. Bjola, Corneliu and Holmes, Marcus [Eds.] [2015]: Digital Diplomacy. Theory and Practice. Routledge New Diplomacy Studies. First Edition. New York: Routlegde.

5. Bjola, Corneliu and Kornprobst, Markus [2018]: Understanding International Diplomacy: Theory, Practice and Ethics. Second Edition. London and New York: Routledge.

6. Bohman, James and Lutz-Bachmann, Matthias [Eds.] [1997]: Perpetual Peace: Essays on Kant's Cosmopolitan Ideal. Cambridge: MIT Press.

7. Brown, Garrett W., and, Held, David [Eds.] [2010]: The Cosmopolitanism Reader. First edition. Cambridge: Polity Press.

8. Chakrabarty, Dipesh, Bhaba, Homi K., Pollock, Sheldon, and, Breckenridge, Carol A. [Eds.] [2002]: Cosmopolitanism. Durham and London: Duke University Press Books.

9. Clunan, Anne L. [2020]: Epistemic community. International Relations. In: https://www. britannica.com/topic/epistemic-community [05.08.2020]

10. Davies, Thomas 2019: Routledge Handbook of NGOs and International Relations. First Edition. London: Routledge.

11. Delanty, George. [Ed.] [2017]: Routledge Handbook of Cosmopolitanism Studies. First edition. London and New York: Routledge.

12. Donnelly, Jack [2000]: Realism and international Relations. Cambridge: Cambridge University Press.

13. Fine, Robert [2007]: Cosmopolitanism. Key Ideas. First edition. London and New York: Routledge.

14. Guzzini, Stefano [1998]: Realism in International relations and International Political Economy: The Continuing Story of a Death Foretold. London: Routledge.

15. Hamilton, Keith and Langhorne, Richard [2010]: The Practice of Diplomacy: Its Evolution, Theory and Administration. Second Edition. London and New York: Routledge.

16. Harari, Yuval Noah [2020]: The world after coronavirus. Financial Times. In: https://www. ft.com/content/19d90308-6858-11ea-a3c9-1fe6fedcca75 [04.04.2020].

17. Herz, Thomas [1951]: Political Realism and Political Idealism: A Study of Theories and Realities. Chicago: University of Chicago Press.

18. International Telecommunication Union [2019]: Measuring Digital Development. Facts and Figures 2019. In: https://www.itu.int/en/ITU-D/Statistics/Documents/Facts/FactsFigures2019. pdf [20.08.2020].

19. Kant, Immanuel [2007]: Perpetual Peace. Originally published in 1795. Minneapolis: Filiquarian Publishing.

20. Kendall, Gavin, Woodward, lan, and, Skrbis, Zlatko [2009]: The Sociology of Cosmopolitanism: Globalization, Identity, Culture and Government. Basingstoke: Palgrave Macmillan.

21. Kerr, Pauline and Wiseman, Geoffrey [2017]: Diplomacy in a Globalizing World. Second Edition. Oxford: Oxford University Press.

22. Kishan, Rana S. [2011]: $21^{\text {st }}$ Century Diplomacy: A Practioner's Guide. First Edition. New York: Continuum.

23. Lechner, Frank J. and Boli, John [Eds.] [2014]: The Globalization Reader. Fifth Edition. Hoboken: Wiley-Blackwell. 
24. Manor, Ilan [2019]: The Digitalization of Public Diplomacy. Palgrave Macmillan Series in Global Public Diplomacy. First Edition. London: Palgrave Macmillan.

25. Ritzer, George [2012]: The Wiley-Blackwell Encyclopedia of Globalization. Hoboken: WileyBlackwell.

26. Ritzer, George and Dean, Paul [2015]: Globalization. A Basic Text. Second Edition. Hoboken: Wiley-Blackwell.

27. Ritzer, George and Dean, Paul [2019]: Globalization. The Essentials. Second Edition. Hoboken: Wiley-Blackwell.

28. Rovisco, Maria, and, Nowicka, Magdalena [Eds.] [2011]: The Ashgate Resarch Companion to Cosmopolitanism. Farnham: Ashgate Publishing.

29. Sandre, Andreas [2015]: Digital Diplomacy: Conversations on Innovation in Foreign Policy. Lanham: Rowman \& Littlefield Publishers.

30. Steger, Manfred B. [2020]: Globalization. A Very Short Introduction. Fifth Edition. Oxford: Oxford University Press.

31. Thomas Hobbes [1982]: Leviathan. Fourth Edition. London: Penguin Classics.

32. UN [2019]: The age of digital interdependence. Report of the High-Level Panel on Digital Cooperation. In: https://digitalcooperation.org/report/ [30.06.2020]

33. UNESCO [2019]: The United Nations world water development report 2019: leaving no one behind. In: https://unesdoc.unesco.org/ark:/48223/pf0000367306 [05.08.2020]

34. United Nations Framework Convention on Climate Change [2015]: The Paris Agreement. In: https://unfccc.int/process-and-meetings/the-paris-agreement/the-paris-agreement [05.08.2020]

35. Waltz, Kenneth N. [2008]: Realism and International Politics. London: Taylor \& Francis Ltd.

36. WBGU - German Advisory Council on Global Change [2019]: Towards our Common Digital Future. Summary. Berlin: WBGU.

37. Williams, Michael C. [2005]: The Realist Tradition and the Limit of International Relations. Cambridge: Cambridge University Press.

38. Williams, Michael C. [2007]: Realism Reconsidered: The Legacy of Hans Morgenthau in International Relations. Oxford: Oxford University Press.

39. Wohlforth, William, C. [2008]: Realism. In: The Oxford Handbook of International Relations. Edited by Christian Reus-Smit and Duncan Snidal [Eds.]. Oxford: Oxford University Press, p.131-149.

40. World Economic Forum [2020]: The Global Risks Report 2020, 15th Edition, World Economic Forum, Geneva. In: http://www3.weforum.org/docs/WEF_Global_Risk_Report_2020.pdf [09.08.2020] 